\title{
PENILAIAN STATUS GIZI SISWI KELAS X DAN XI DI SMAN 1 DEPOK, KABUPATEN SLEMAN, YOGYAKARTA
}

\author{
Sicilia $^{1}$, Reni Merta Kusuma ${ }^{1}$ \\ ${ }^{1}$ Program studi D3 Kebidanan Stikes Jenderal Achmad Yani Yogyakarta \\ Jl. Ringroad Barat, Ambarketawang, Gamping, Sleman, D.I.Yogyakarta
}

\begin{abstract}
Background: Teenagers, especially femalearesusceptible to problems related to malnutrition such as Chronic Energy Deficiency (CED).

Objective: To determine the characteristics of nutritional status based on age, weight, height, arm circumference, and Body Mass index (BMI) in X and XI grade students at SMAN 1 Depok, Sleman District, Yogyakarta.

Method: The study was an observational study with cross-sectional approach. Measurement used a digital scale, mikrotoise, and upper arm circumference tape. Subjects in this study were 250 female teenagers. Descriptivequantitative analysis was employed for data with numerical/continuous scale (ratio and interval).

Results: The majority of female teenagers aged between 14-18 years (mean=16yo). The meanweight was $50.58 \mathrm{~kg}$, the meanheightwas $155.65 \mathrm{~cm}$, and the mean size of the upper-arm circumference was $24.9 \mathrm{~cm}$. The measurement showed the mean BMI was $20.9 \mathrm{~kg} / \mathrm{m} 2$. Ten percent of students were categorized as severeunderweight (severe CED) and $7.2 \%$ were in the obesecategory. Measurement of nutritional status with upper-arm circumference showed $33.6 \%$ female teenagerswere at risk of CED.

Conclusion: There were female teenagerswho had problems with nutritional status (severe underweight and obese). Upper-arm circumference measurement results showed $33.6 \%$ of teenagers were at risk of CED.
\end{abstract}

Keyword: Nutritional status, BMI, upper-arm circumference, CED

\section{PENDAHULUAN}

Hasil Riset Kesehatan Dasar menunjukkan prevalensi Wanita Usia Subur (WUS) Provinsi Daerah Istimewa Yogyakarta (DIY) yang masuk dalam kategori Kekurangan Energi Kronis (KEK) cukup tinggi sebesar $21 \%$. ${ }^{(1)}$ Angka tersebut merupakan angka tertinggi ketiga di Indonesia dibanding kota lain. Situasi kesehatan lain yang secara kualitas melebihi provinsi lain seperti kematian ibu, bayi, dan balita, sanitasi lingkungan, penyakit, dan lain sebagainya, maka kondisi DIY tersebut menjadi sebuah pertanyaan besar bagi para pemangku kepentingan terkait di provinsi lain. Survei Kesehatan Dasar (Surkesdas) yang diselenggarakan Dinas Kesehatan (Dinkes)
Provinsi DIY tahun 2010 lanjutan dari Riskesdas Kementerian Kesehatan RI menunjukkan prevalensi KEK lebih tinggi terjadi di wilayah perkotaan dengan angka tertinggi di Kabupaten Sleman sebesar $21,71 \%$. $^{(2)}$

Zat gizi merupakan unsur yang penting dalam kebutuhan nutrisi mengingat zat gizi tersebut dapat memberikan fungsi tersendiri pada nutrisi. Kebutuhan nutrisi tidak akan berfungsi secara optimal apabila tidak mengandung beberapa zat gizi yang sesuai untuk kebutuhan tubuh. Konsumsi gizi sangat memengaruhi status gizi kesehatan seseorang sebagai modal utama bagi tubuh manusia. Asupan gizi yang salah atau tidak 
sesuai akan menimbulkan masalah pada kesehatan. ${ }^{(3)}$

Gizi merupakan salah satu penentu kualitas sumber daya manusia, kekurangan gizi akan mengakibatkan kegagalan pertumbuhan fisik dan perkembangan kecerdasan, menurunkan produktivitas kerja, dan menurunkan daya tahan tubuh yang berakibat meningkatnya angka kesakitan dan kematian. Kecukupan gizi sangat diperlukan oleh setiap individu, sejak janin yang masih di dalam kandungan, bayi, anak-anak, masa remaja, dewasa, sampai usia lanjut. Ibu atau calon ibu merupakan kelompok rawan, karena membutuhkan gizi yang cukup sehingga harus dijaga status gizi dan kesehatannya, agar dapat melahirkan bayi yang sehat. ${ }^{(4)}$

Masalah gizi di Indonesia dan di negara berkembang hingga saat ini masih di dominasi oleh masalah Kekurangan Energi Protein (KEP), KEK, Anemia Gizi Besi (AGB), Gangguan Akibat Kekurangan Yodium (GAKY), Kekurangan Vitamin A (KVA), dan masalah obesitas terutama di kota-kota besar. ${ }^{(5)}$

Kelompok yang dapat mengalami kejadian rentan gizi menurut pendapat Sediaoetama ialah masyarakat yang paling mudah menderita kelainan gizi apabila terkena kekurangan bahan makanan. Kelompok ini umumnya mengalami kondisi rentan gizi berhubungan dengan proses pertumbuhan yang relatif pesat, yang memerlukan zat gizi dalam jumlah relatif besar namun asupan ke dalam tubuh tidak sesuai/kurang. Kelompok rentan gizi ini ialah: bayi, balita, anak sekolah, remaja, ibu hamil, dan ibu menyusui. ${ }^{(6)}$

KEK merupakan salah satu permasalahan gizi di Indonesia yang banyak dialami oleh WUS termasuk remaja, ibu hamil, dan ibu menyusui. ${ }^{(7)}$ KEK pada WUS merupakan faktor risiko kematian pada ibu hamil dan janin. Manifestasi dari masalah gizi makro apabila terjadi pada WUS dan ibu hamil yang mengalami KEK adalah Bayi Berat Lahir Rendah (BBLR). Pola makan yang belum baik dipengaruhi oleh kebutuhan terkait dengan estetik atau penampilan dalam rangka menjaga bentuk tubuh dibandingkan aspek ekonomi.

KEK pada remaja dan WUS dapat disebabkan oleh penyebab langsung seperti penyakit dan pola konsumsi, serta penyebab tidak langsung seperti umur, pendidikan, dan pekerjaan. Status gizi dapat diukur dengan menggunakan pita Lingkar Lengan Atas (LiLA). ${ }^{(5)}$ Pengukuran dengan pita LiLA pada orang dewasa merupakan salah satu pilihan terbaik karena mudah dilaksanakan dan menggunakan alat ukur yang murah serta mudah diperoleh. Survei Kesehatan Daerah DIY (2010) menyatakan bahwa rerata LiLA WUS di DIY $(26,28 \mathrm{~cm})$ lebih tinggi dari hasil Riskesdas $2007(26,18 \mathrm{~cm})$. $^{(2)}$

WUS juga meliputi masa remaja dilihat dari batasan usia seperti definisi remaja menurut Perserikatan Bangsa-Bangsa (PBB) yang menyebut kaum muda (youth) untuk 
usia 15 sampai dengan 24 tahun. Remaja adalah periode perkembangan selama individu mengalami perubahan dari masa kanak-kanak menuju masa dewasa. Rentang usia remaja biasanya antara usia 13 dan 20 tahun. ${ }^{(8)}$ Remaja sering didefinisikan sebagai masa transisi antara masa anak-anak ke masa dewasa atau masa belasan tahun. Masa remaja merupakan waktu kematangan fisik, kognitif, sosial, dan emosional yang cepat pada anak perempuan untuk mempersiapkan diri menjadi wanita dewasa. $^{(9)}$

Badan Pusat Statistik (BPS) Kabupaten Sleman menyebutkan bahwa jumlah WUS tertinggi terdapat di Kecamatan Depok dengan usia 13-15 tahun sebanyak 6.253 jiwa dan usia 16-18 tahun sebanyak 2.935 jiwa, hal ini dimaksudkan sebagai salah satu alternatif melihat gambaran status gizi WUS dengan populasi terbanyak di Kabupaten Sleman. ${ }^{(10)}$

Kelompok umur 15 tahun sampai dengan 18 tahun lebih spesifik masuk dalam kategori remaja yang banyak didominasi berada di Sekolah Menengah Atas (SMA), Organisasi Kesehatan Dunia $(W H O)$ juga menyebutkan bahwa periode usia remaja berada antara usia 10-19 tahun. ${ }^{(11)}$ Kecamatan Depok memiliki satu-satunya SMA Negeri yang berada di kecamatan ini yaitu SMAN 1 Depok. Sekolah Menengah Atas (SMA) negeri lebih banyak diminati oleh remaja dengan tingkat penghasilan orangtua yang tidak dibatasi, baik kurang maupun berkecukupan, sehingga mayoritas orangtua mengarahkan anaknya untuk memilih sekolah negeri dengan biaya yang cukup terjangkau.

Perilaku makan pelajar dalam memilih jenis makanan dipengaruhi oleh beberapa faktor seperti budaya, sosial, pribadi, dan psikologis. Dari beberapa faktor tersebut faktor budaya paling banyak memberikan pengaruh pada pola konsumsi pelajar, hal ini disebabkan oleh berkembangnya pengetahuan dan informasi mengenai jenis makanan dan minuman yang disajikan di seluruh penjuru kota melalui media massa. ${ }^{(12)}$

Status gizi wanita sebelum kehamilan menjadi salah satu penentu indikator kesehatan dalam proses kehamilan, dan akibat pengaruh tingginya prevalensi penyakit KEK yang dialami wanita baik sebelum kehamilan maupun saat kehamilan sangat berisiko bagi pertumbuhan dan perkembangan janin yang akan dilahirkan seperti terjadinya BBLR. Laporan Dinas Kesehatan Provinsi DIY juga menyatakan bahwa dari kelima provinsi setempat kasus tertinggi terjadi di Kabupaten Sleman, maka berdasarkan data kejadian kasus KEK diatas serta akibat dari penyakit KEK yang dapat terjadi, sehingga peneliti tertarik untuk meneliti gambaran status gizi remaja SMA terkait permasalahan KEK pada kelas $X$ dan XI kecuali kelas XII, dengan menggunakan penilaian IMT dan LiLA di SMAN 1 Depok, Kabupaten Sleman tahun 2014. 
Tujuan penelitian ini untuk mengetahui gambaran status gizi siswa kelas $\mathrm{X}$ dan XI dengan mengidentifikasi umur responden, ukuran berat badan, tinggi badan, lingkar lengan, dan indeks massa tubuh.

\section{BAHAN DAN CARA PENELITIAN}

Penelitian ini menggunakan penelitian deskripsi kuantitatif dengan jenis penelitian adalah observasional dengan rancangan penelitian cross sectional (potong lintang). Penelitian ini dilakukan di SMAN 1 Depok, Kabupaten Sleman, Yogyakarta. Populasi penelitian adalah siswi SMAN 1 Depok kelas $X$ dan $\mathrm{XI}$ yang berjumlah 268 siswi, namun ada 18 siswi yang tidak hadir saat pengambilan data. Teknik sampling menggunakan total sampling atau pemilihan keseluruhan populasi untuk mendapatkan data yang lebih menyeluruh. Kriteria inklusi dalam penelitian ini adalah (1) tidak sedang menderita penyakit seperti jantung (misalnya stroke, jantung koroner, dan sebagainya), diabetes, tuberculosis (TBC), penyakit paru, (2) bersedia mengikuti penelitian dengan menandatangani lembar persetujuan. Kriteria eksklusi dalam penelitian ini adalah tidak hadir saat pengambilan data penelitian.

Alat atau instrumen yang digunakan dalam penelitian ini di antaranya :

1. Timbangan untuk menimbang berat badan dewasa, jenis digital merek Camry.

2. Microtoise untuk mengukur tinggi badan,
3. Pita LiLA untuk mengukur Lingkar Lengan Atas,

4. Kalkulator untuk menghitung Indeks Massa Tubuh (IMT).

Teknik pengumpulan data dilakukan dengan pengukuran secara langsung untuk mendapatkan data primer. Data karakteristik responden yang meliputi umur, agama, dan riwayat penyakit 6 bulan lalu diperoleh dari menanyakan secara biasa/umum. Pengukuran antropometri dilakukan untuk mendapatkan data tentang status gizi.

Pengukuran status gizi dalam penelitian ini dilakukan dengan dua metode yaitu lingkar lengan atas (LiLA) dan status IMT. Status IMT dilakukan dengan melakukan pengukuran berat badan dan tinggi badan. Berat badan diukur dengan timbangan dewasa digital, sedangkan untuk tinggi badan dengan microtoise. Data yang sudah didapatkan, selanjutnya dicatat dengan menggunakan formulir khusus.

\section{HASIL DAN PEMBAHASAN}

Lingkar Lengan Atas (LiLA)

Data hasil analisis LiLA responden kelas $X$ dan XI dapat dilihat pada tabel 1 di bawah ini.

Tabel 1 Rata-Rata LiLA Siswi Kelas $X$ dan XI di SMAN 1 Depok Tahun 2014

\begin{tabular}{cccccc}
\hline Variabel & Mean & Median & SD & $\begin{array}{c}\text { Minimal- } \\
\text { Maksimal }\end{array}$ & $\begin{array}{c}95 \\
\% \mathrm{Cl}\end{array}$ \\
\hline \multirow{2}{*}{ LiLA } & $\begin{array}{c}24.9 \\
\mathrm{~cm}\end{array}$ & $\begin{array}{c}24.5 \\
\mathrm{~cm}\end{array}$ & 3.10 & $\begin{array}{c}17-39 \\
\mathrm{~cm}\end{array}$ & $\begin{array}{c}24.58- \\
25.35 \\
\mathrm{~cm}\end{array}$
\end{tabular}

Tabel 1 menunjukkan hasil analisis data LiLA responden kelas $X$ dan $\mathrm{XI}$ di SMAN 1 
Depok. Rerata LiLA siswi adalah $24.9 \mathrm{~cm}$ dan ukuran LiLA terkecil yaitu $17 \mathrm{~cm}$. Hasil estimasi interval dapat disimpulkan 95\% diyakini bahwa rata-rata LiLA siswi di SMAN 1 Depok tahun 2014 adalah antara $24.58 \mathrm{~cm}$ sampai $25.35 \mathrm{~cm}$.

Data hasil pengukuran LiLA responden kelas $\mathrm{X}$ dan $\mathrm{XI}$ dapat dilihat pada tabel 2 di bawah ini.

Tabel 2 Distribusi Frekuensi LiLA Siswi Kelas X dan XI di SMAN 1 Depok Tahun 2014

\begin{tabular}{cccc}
\hline No. & Kategori LiLA & Jumlah $(\mathrm{n})$ & $\begin{array}{c}\text { Persentase } \\
(\%)\end{array}$ \\
\hline 1 & KEK $(<23.5 \mathrm{~cm})$ & 84 & 33.6 \\
\hline 2 & $\begin{array}{c}\text { Tidak KEK }(\geq 23.5 \\
\mathrm{cm})\end{array}$ & 166 & 66.4 \\
\hline & Total & 250 & 100 \\
\hline
\end{tabular}

Tabel 2 menunjukkan hasil pengukuran

LiLA responden kelas $X$ dan XIdi SMAN 1 Depok. Siswi yang masuk kategori KEK cukup tinggi sekitar 84 orang siswi (33.6\%).

Nilai Indeks Massa Tubuh (IMT)

Data nilai IMT siswi kelas $X$ dan $X I$ dapat dilihat pada tabel 3 berikut ini.

Tabel 3 Distribusi Nilai IMT Siswi Kelas X dan XI di SMAN 1 Depok Tahun 2014

\begin{tabular}{llllll}
\hline Variabel & Mean & Median & SD & $\begin{array}{l}\text { Minimal- } \\
\text { Maksimal }\end{array}$ & $\begin{array}{l}95 \\
\% \mathrm{Cl}\end{array}$ \\
\hline $\begin{array}{lllll}\text { Nilai } \\
\text { IMT }\end{array}$ & 20.9 & 20.13 & \multirow{2}{*}{3.7} & $\begin{array}{l}12.83- \\
\begin{array}{l}38.23 \\
\mathrm{Kg} / \mathrm{m}^{2}\end{array}\end{array}$ & $\begin{array}{l}21.35- \\
\mathrm{Kg} / \mathrm{m}^{2}\end{array}$ \\
\hline
\end{tabular}

Tabel 3 menunjukkan hasil analisis data nilai IMT responden. Nilai IMT responden tertinggi adalah $38.23 \mathrm{Kg} / \mathrm{m}^{2}$. Hasil estimasi interval dapat disimpulkan 95\% diyakini ratarata nilai IMT siswi di SMAN 1 Depok tahun 2014 adalah antara $20.43 \mathrm{Kg} / \mathrm{m}^{2}$ sampai dengan $21.35 \mathrm{Kg} / \mathrm{m}^{2}$.

\section{Status Gizi Berdasarkan IMT}

Status gizi ditinjau berdasarkan ukuran BB dan TB yang dihitung dengan rumus IMT untuk melihat gambaran nilai IMT responden di SMAN 1 Depok dapat dilihat pada tabel 4.8 berikut ini.

\section{Tabel 4 Distribusi Frekuensi Status Gizi Siswi Kelas X dan XI Berdasarkan Nilai IMT di SMAN 1 Depok Tahun 2014}

\begin{tabular}{clcc}
\hline No. & Klasifikasi IMT & $\begin{array}{c}\text { Jumlah } \\
(\mathrm{n})\end{array}$ & $\begin{array}{c}\text { Perse } \\
\text { ntase } \\
(\%)\end{array}$ \\
\hline 1 & Kurus Tingkat Berat & 25 & 10 \\
\hline 2 & $\begin{array}{l}\text { Kurus Tingkat } \\
\text { Ringan }\end{array}$ & 43 & 17.2 \\
\hline 3 & Normal & 153 & 61.2 \\
\hline 4 & $\begin{array}{l}\text { Gemuk Tingkat } \\
\text { Ringan }\end{array}$ & 11 & 4.4 \\
\hline 5 & $\begin{array}{l}\text { Gemuk Tingkat } \\
\text { Berat }\end{array}$ & 18 & 7.2 \\
\hline \multicolumn{1}{c}{ Total } & 250 & 100 \\
\hline Hasil perhitungan IMT dari BB dan TB
\end{tabular}

responden kelas $\mathrm{X}$ dan $\mathrm{XI}$ pada tabel 4 menunjukkan sebanyak 25 orang responden (10\%) masuk dalam kategori kurus tingkat berat, dan juga terdapat 18 orang responden $(7.2 \%)$ yang masuk dalam kategori gemuk tingkat berat.

\section{PEMBAHASAN PENELITIAN}

Hasil penelitian menunjukkan bahwa remaja putri kelas $X$ dan XI di SMAN 1 Depok berumur antara 14-18 tahun. Hal ini sesuai dengan definisi remaja adalah kaum muda (young people) yang mencakup usia 10-24 tahun. ${ }^{(11)}$

Umur setingkat remaja atau kaum muda banyak yang memiliki gizi tidak seimbang. Hal ini dipengaruhi oleh pola perilaku makan 
dan pemilihan jenis makanan dipengaruhi oleh beberapa faktor terutama dari faktor budaya yang disebabkan oleh perkembangan pengetahuan dan informasi mengenai jenis makanan dan minuman yang disajikan melalui media massa. ${ }^{12}$ Remaja saat ini juga cenderung lebih banyak makan di luar rumah dan banyak dipengaruhi oleh teman, media informasi terutama di daerah perkotaan yang banyak meniru gaya hidup modern. ${ }^{(3)}$ Kondisi remaja saat ini lebih suka mengonsumsi makanan yang termasuk dalam tipe cepat saji (junk food) dan instan yang komposisi gizinya tidak seimbang bahkan cenderung kurang. Hasil penelitian ini dapat menggambarkan ketidakseimbangan gizi para remaja di SMAN 1 Depok dapat dilihat pada nilai BB siswi yang 47,2\% berumur 16 tahun memiliki range antara 30,2 $\mathrm{Kg}$ hingga $88,1 \mathrm{Kg}$ dengan $95 \% \mathrm{Cl}$ antara $49,41 \mathrm{Kg}$ hingga $51,75 \mathrm{Kg}$. Pola makan yang tidak seimbang pada remaja menyebabkan rentan terjadinya masalah $\mathrm{BB}$ seperti obesitas dan berat badan kurang atau kurus. Berat badan(BB) dan TB adalah salah satu parameter penting untuk menentukan status kesehatan manusia khususnya gizi.

Berat Badan (BB) dan TB dapat digunakan untuk menilai status gizi dengan IMT. Indeks Massa Tubuh (IMT) merupakan parameter untuk menilai status gizi secara lebih terukur. Dasar penggunaan parameter IMT memiliki beberapa versi yaitu penggunaan IMT berlaku untuk orang dewasa berumur di atas 18 tahun, dan tidak dapat diterapkan pada bayi, anak, remaja, ibu hamil, dan olahragawan. ${ }^{5,13}$ Direktorat Gizi Masyarakat dalam Surveilans Gizi yang menyatakan bahwa IMT dapat digunakan untuk melihat gambaran status gizi WUS usia 15-45 tahun. ${ }^{14}$ Hal ini juga didukung dari pendapat Almatsier yaitu perbandingan (rasio) berat badan/tinggi badan banyak digunakan untuk menilai keseimbangan BB dan TB orang dewasa dan remaja. ${ }^{15}$ Penelitian ini menggunakan parameter IMT secara umum untuk menggambarkan status gizi remaja putri dengan dasar dari sumbersumber yang ada.

Hasil pengukuran dan perhitungan IMT siswi kelas $\mathrm{X}$ dan $\mathrm{XI}$ menunjukkan rerata nilai IMT siswi adalah $20,9 \mathrm{Kg} / \mathrm{m}^{2}$ yang masuk dalam kategori BB ideal (normal), namun terdapat $10 \%$ siswi masuk dalam kategori kurus dengan kekurangan BB tingkat berat (KEK berat), dan 17,2\% dalam kategori kurus dengan kekurangan BB tingkat ringan (KEK ringan) yaitu $B B$ responden kurang ideal dan disarankan perbanyak mengonsumsi makanan berkalori. KEK merupakan suatu keadaan kekurangan makanan yang terjadi dalam waktu lama sehingga menyebabkan nilai IMT di bawah normal $(<18.5$ $\left.\mathrm{Kg} / \mathrm{m}^{2}\right) \cdot{ }^{16} \mathrm{Hasil}$ klasifikasi status gizi berdasarkan IMT berikutnya menunjukkan 11 orang dari 250 orang responden (4.4\%) masuk dalam klasifikasi gemuk dengan kelebihan BB tingkat ringan, artinya BB masih ideal namun hampir mencapai obesitas, responden disarankan untuk menjaga pola 
makan dan memperbanyak olahraga, dan $7.2 \%$ siswi berada dalam kategori IMT $>27.0$ $\mathrm{Kg} / \mathrm{m}^{2}$ yaitu gemuk dengan kelebihan BB tingkat berat, BB melebihi ideal, dan menderita obesitas. Berat normal adalah idaman bagi setiap orang agar mencapai tingkat kesehatan yang optimal. Keuntungan memiliki BB ideal adalah memiliki penampilan yang baik, lincah, dan risiko untuk terkena penyakit lebih rendah. Berat badan (BB) yang kurang atau berlebihan akan menimbulkan risiko terhadap berbagai macam penyakit. ${ }^{5}$

Pengukuran pendukung IMT untuk melihat status gizi remaja adalah LiLA. Hasil pengukuran menunjukkan rerata ukuran LiLA siswi SMAN 1 Depok adalah $24.9 \mathrm{~cm}$ yang dalam klasifikasi masuk dalam kategori normal $(\geq 23.5 \mathrm{~cm})$. Ambang batas LiLA untuk ibu hamil, WUS, dan remaja dengan risiko KEK di Indonesia adalah $23.5 \mathrm{~cm}$, apabila ukuran LiLA $<23.5 \mathrm{~cm}$ atau di bagian merah pita LiLA artinya wanita tersebut memiliki risiko mengalami KEK. ${ }^{5}$ Hasil penelitian menunjukkan bahwa $33.6 \%$ dari 250 orang remaja putri di SMAN 1 Depok masuk dalam kategori wanita yang berisiko mengalami KEK. Hasil data LiLA ukuran $<23.5 \mathrm{~cm}$ untuk perempuan yang menderita KEK pada usia 15-49 tahun mencapai 15\%, sedangkan pada remaja putri mencapai $37 \%$ walaupun hasil data ukuran LiLA siswi yang tidak mengalami KEK sebesar $66.4 \%$. Hal ini berbeda dengan hasil yang ditunjukkan dari ukuran BB yang memiliki range $57.9 \mathrm{Kg}$ yaitu antara $30.2 \mathrm{Kg}$ hingga $88.1 \mathrm{Kg} .{ }^{17}$
Persentase remaja putri yang berisiko mengalami KEK cukup tinggi mengisyaratkan bahwa pencegahan risiko KEK pada remaja putri perlu dilakukan sejak sebelum hamil agar wanita dapat memulai kehamilan dan menyusui terhindar dari risiko KEK. Pencegahan dapat dilakukan dengan pemberian makanan tambahan tinggi energi, dan melakukan promosi kesehatan agar ibu dapat memulai kehamilan dan menyusui dengan status gizi baik, cukup energi dan zat gizi. ${ }^{7}$ Perbaikan status gizi remaja putri akan lebih baik dilakukan sedini mungkin, remaja pun telah memiliki dasar pengetahuan tentang sumber nutrisi yang baik bagi tubuh. Promosi kesehatan oleh lembaga kesehatan terkait seperti puskesmas dapat dilakukan dengan tema yang bervariasi dalam mengupayakan perbaikan gizi remaja untuk lebih baik, namun tentunya perbaikan gizi harus didukung oleh tenaga pengajar sebagai pembimbing selama di sekolah dan orangtua sebagai orang yang mampu mengontrol dan mengarahkan remaja khususnya remaja putri untuk memilih bahan makanan yang berkualitas dan tentunya sehat, serta membiasakan diri sarapan pagi untuk membantu para siswi memiliki gizi yang lebih baik, sehingga jumlah kejadian KEK dan obesitas dapat berkurang. Responden penelitian ini tidak ada yang memiliki riwayat penyakit seperti jantung (misalnya stroke, jantung koroner, dan sebagainya), diabetes, tuberculosis (TBC), dan penyakit paru dalam \pm 6 bulan sebelum pengambilan data 
penelitian sehingga tidak memengaruhi hasil akhir dari pengukuran status gizinya.

\section{KESIMPULAN}

Hasil penelitian menunjukkan sebagian besar remaja putri kelas $X$ dan $\mathrm{XI}$ di SMAN 1 Depok berumur antara 14 sampai dengan 18 tahun dan rata-rata berumur 16 tahun. Rerata BB siswi $50.58 \mathrm{Kg}$, dan rerata TB siswi $155.65 \mathrm{~cm}$, yang termasuk normal. Rerata ukuran LiLA siswi adalah $24.9 \mathrm{~cm}$ yang termasuk normal. Hasil pengkuran status gizi dengan LiLA menunjukkan $33.6 \%$ dari 250 orang remaja putri memiliki ukuran LiLA $<23.5 \mathrm{~cm}$.

Rerata nilai IMT siswi adalah $20.9 \mathrm{Kg} / \mathrm{m}^{2}$ yang masuk kategori status gizi normal $\left(18.5-25.0 \mathrm{Kg} / \mathrm{m}^{2}\right)$. Hasil pengukuran IMT menyatakan $10 \%$ siswi memiliki nilai $<17$ $\mathrm{Kg} / \mathrm{m}^{2}$ yang masuk kategori kurus dengan kekurangan BB tingkat berat (KEK berat) dan $7.2 \%$ siswi memiliki nilai $>27 \mathrm{Kg} / \mathrm{m}^{2}$ yang masuk kategori gemuk dengan kelebihan BB tingkat berat (menderita obesitas).

\section{KEPUSTAKAAN}

1. Riskesdas. Pedoman Pengukuran dan Pemeriksaan. Jakarta. Badan Penelitian dan Pengembangan Departemen $\begin{array}{lll}\text { Kesehatan } & \text { RI. } & 2007\end{array}$ (http://www.scribd.com/doc/171155528/P edoman-Pengukuran) Diakses pada 17 Desember 2013.
2. Dinkes DIY. Kurang Energi Kronis dan Permasalahan pada Wanita Usia Subur, Yogyakarta: Dinkes DIY. 2011

3. Sulistyoningsih, Hariyani. Gizi Untuk Kesehatan Ibu dan Anak, Yogyakarta: Graha IImu. 2012

4. Direktorat Gizi Masyarakat. Program Penanggulangan Anemia Gizi pada Wanita Usia Subur (WUS) (Safe Motherhood Project: A Partnership and Family Approach/Kesehatan Ibu: Kemitraan dan Pendekatan Keluarga). Jakarta: Departemen Kesehatan RI. 2008

5. Supariasa, I. D. N., Bakri, B. \& Fajar, I. Penilaian Status Gizi, Jakarta: BukuKedokteran EGC. 2012

6. Yuliantini, Hasri., Mifbakhuddin. Hubungan Antara Konsumsi Energi dan Protein dengan Status Gizi pada Ibu Hamil di Wilayah Kerja Puskesmas I Sukoharjo. 2004. Jurnal Kesehatan Masyarakat Indonesia, Vol I No.2

7. Perry dan Potter. Buku Ajar Fundamental Keperawatan Konsep, Proses, Dan Praktik. Volume 1, Edisi 4. Jakarta: EGC. 2005

8. Irawati, Anies. Faktor Determinan Risiko Kurang Energi Kronis (KEK) pada Ibu Menyusui di Indonesia, Puslitbang Gizi dan Makanan (PGM). 2009: 32(2): 8293.

9. Badan Pusat Statistik (BPS) Kabupaten Sleman. Kabupaten Sleman dalamAngka (Sleman Regency in Figures). 
Yogyakarta: Badan Pusat Statistik Kabupaten Sleman. 2013

10. Kusmiran, E. Kesehatan Reproduksi Remaja dan Wanita. Jakarta: Salemba Medika. 2011

11. Fakhruddin, S. Perilaku Makan Remaja Terhadap Makanan Cepat Saji di Kota Makassar. Makassar: 2009. Jurusan Antropologi Fakultas IImu Sosial dan Ilmu Politik Universitas Hassanuddin.

12. Waryana. Gizi Reproduksi, Yogyakarta: Pustaka Rihama. 2010

13. Direktorat Gizi Masyarakat. Surveilans Gizi. Jakarta: Kementerian Kesehatan RI. 2012

14. Almatsier, Sunita., Soetardjo, S., Soekatri, M. Gizi Seimbang dalam Daur Kehidupan, Jakarta: PT.Gramedia Pustaka Utama. 2011

15. Persagi. Kamus Gizi Pelengkap Kesehatan Keluarga, Jakarta: Buku Kompas. 2009

16. Sadli, Saparinah. Berbeda Tetapi Setara (Pemikiran tentang Kajian Perempuan), Jakarta: Buku Kompas. 2010 